\title{
Public Participation and Agency in Art Museums
}

Citation for published version (APA):

Sitzia, E. (2019). Public Participation and Agency in Art Museums. In B. Eriksson, C. Stage, \& B. Valtysson (Eds.), Cultures of Participation : Arts, Digital Media and Cultural Institutions (pp. 185-200). Routledge/Taylor \& Francis Group. https://doi.org/10.4324/9780429266454-11

Document status and date:

Published: 01/01/2019

DOI:

10.4324/9780429266454-11

Document Version:

Publisher's PDF, also known as Version of record

Document license:

Taverne

\section{Please check the document version of this publication:}

- A submitted manuscript is the version of the article upon submission and before peer-review. There can be important differences between the submitted version and the official published version of record.

People interested in the research are advised to contact the author for the final version of the publication, or visit the DOI to the publisher's website.

- The final author version and the galley proof are versions of the publication after peer review.

- The final published version features the final layout of the paper including the volume, issue and page numbers.

Link to publication

\footnotetext{
General rights rights.

- You may freely distribute the URL identifying the publication in the public portal. please follow below link for the End User Agreement:

www.umlib.nl/taverne-license

Take down policy

If you believe that this document breaches copyright please contact us at:

repository@maastrichtuniversity.nl

providing details and we will investigate your claim.
}

Copyright and moral rights for the publications made accessible in the public portal are retained by the authors and/or other copyright owners and it is a condition of accessing publications that users recognise and abide by the legal requirements associated with these

- Users may download and print one copy of any publication from the public portal for the purpose of private study or research.

- You may not further distribute the material or use it for any profit-making activity or commercial gain

If the publication is distributed under the terms of Article $25 \mathrm{fa}$ of the Dutch Copyright Act, indicated by the "Taverne" license above, 


\title{
11 Public participation and agency in art museums
}

\author{
Emilie Sitzia
}

In the last few decades, art museums have seen a shift in their perceived roles and the contexts in which they operate. The perception of the role of the art museum has gradually transformed from an institution solely presenting and defending the culture(s) of the elite (Jordan \& Weedon 1995; Bal 1996; Ferguson, Greenberg \& Nairne 1996; Borg \& Mayo 2010; McCall \& Gray 2014; Clover 2015), to one also promoting alternative forms of content, knowledge transfer and production. Within the framework of the new museology, museums saw attempts at democratization and at the representation of multiple voices by working with communities to provide critical views of museums' history, theories and practices (Dewey 1916/2008; Vergo 1989; Mairesse \& Desvallées 2007). From seeing the museum as a "contact zone" (Clifford 1999), to a social inclusion tool (Sandell 1998, 2002, 2003) and a constructivist terrain of knowledge production (Hein 1999; Falk \& Dierking 2000), the museum has taken on a wide range of new potential roles. ${ }^{1}$ These multifarious roles are sometimes contradictory and at odds with more general expectations regarding the traditional role of museums. Art museums are simultaneously asked to serve as a temple of the elite's art and as an instrument for democratic emancipation (Nochlin 1972; Sitzia 2017). Museums, therefore, are not neutral spaces and the forms of participation, modes of presentation and content they offer to audiences determine their position in society. As Clover noted, "Public art galleries and museums do take sides" (Clover 2015, p. 303).

As the function of the museum was questioned, the perception of the role of audiences within museums also changed. As Hooper Greenhill wrote, "The age of the passive visitor has passed, to be superseded by the age of the active and discriminating 'consumer' or 'client"' (HooperGreenhill 1992, pp. 210-211). While Hooper-Greenhill's consumerist presentation might seem grim, it also denotes recognition of the active roles visitors now play in institutions. As a consequence of this shift in the role of the art museum and that of its audience, the perception of learning in that space has also shifted. ${ }^{2}$ From a unidirectional and authoritative model, learning in art museums is now widely understood as multiform. ${ }^{3}$ 


\section{Emilie Sitzia}

For the purpose of this chapter I will focus on art museums because the narratives and interpretations of artworks stay relatively open to audience contribution, especially when it comes to attributing meaning or constructing narratives related to artworks. As Ferguson remarked, "the idea that meanings are impossibly unstable is embraceable because inevitable. With works of art, meanings are only produced in context and that is a collective, negotiated, debated and shifting consensual process of determination" (1996, p. 186). This instability of meaning and fluid official narratives has led to a great variety of participatory practices (Sitzia 2018) and to the general claim that art and art museums are potential tools for audience emancipation (Jung 2010; Clover 2015; Sitzia 2017). So-called participatory practices have become omnipresent in art museums. ${ }^{4}$

This chapter analyses how participatory practices in art museums build diverse forms of public agency. I will first investigate what public agency is in the context of the art museum, how it relates to key concepts such as empowerment, ownership, knowledge creation and learning. I will also present what kind of agency is created, allowed and acceptable in the art museum. I will then look closely at the relationship between various forms of participatory practices in art museums and agency. I will focus on three key types of participatory practices that are particularly productive in terms of public agency: meaning making, co-creation of artworks or events and participatory collection management activities. ${ }^{5}$ For each of these three practices I will investigate, on theoretical grounds, the level of agency, the output and the educational framework of such practices. For each practice, I will therefore ask:

- what kind of public agency is created?

- who benefits in terms of knowledge production?

- what kind of power relationship and agency dynamic is implied in the learning models underpinning such participatory practices?

Investigating participation through agency, this chapter aims to contribute to the theoretical debates about the role and impact of participation in the arts. This chapter positions itself firmly in the field of art museum participation and cultural education. It aims to focus on matters of knowledge creation, learning, engagement and ultimately emancipation of the participant through public agency. In this regard, this chapter builds on the works of the likes of Richard Sandell, Eilean Hooper-Greenhill, Nina Simon, Jacques Rancière, Yuha Jung and Bernadette Lynch.

\section{Museums as battlefields of agency: Public agency in the museum}

Museums have been presented as "frontier" zones; that is, zones "where learning is created, new identities are forged; new connections are made 
between disparate groups and their own histories" (Golding 2009, p. 4; Philip 1992). This "frontier" could also be seen as a battlefield of agencies. In this regard, art museums are particularly interesting as not only do they often make visible this battle of agency, but their content also allows them to experiment, reevaluate dominant narratives and involve audiences in creative ways.

\section{Defining agency in art museums}

Defining agency in the art museum is a difficult task; however, it is important to distinguish agency from empowerment and ownership, two terms that are unfortunately often used in literature and in practice as equivalent to agency. Empowerment is a possible result of agency, but it is distinct from it and is socially and culturally determined. While agency and empowerment often go hand in hand, it is not unimaginable that a specific group or target visitor feels empowered in a museum without necessarily having agency in the matter. For example, being represented in a collection has proven to contribute to feelings of empowerment even though the agency in terms of selecting or exhibiting the artwork does not rest with the audience. Lynch (2017) has convincingly shown that "inclusive" practices can very easily become problematic token practices when the agency of the participant is not respected. Social inclusion ideals and empowerment do not necessarily go hand in hand.

Ownership, another term often conflated with agency, is also a possible result of agency but is distinct from it. Ownership has more to do with autobiography and self-narrative. No intention is necessary for a sense of ownership to develop. Once again, if a specific artwork is encountered and triggers a sense of ownership (belonging to one's own frame of cultural reference), while there is a visible outcome (belonging), no action is needed on the part of the audience (aside from taking ownership), nor is there an original intention on the part of the visitor.

While there are a number of museum scholars who have worked on agency in the museum context (for example, see Fyfe 1995; Sandell 2002; Kirchberg 2007; Coffee 2008; Cameron 2015), a specific definition of agency that is operationalisable in terms of empirical research and evaluation - two key aspects of participatory practices research - is still missing from the art museum studies field. Rather, it is in another field, that of video game studies, that agency is most relevantly and precisely defined. Indeed for Mateas:

Agency is the feeling of empowerment that comes from being able to take actions in the world whose effects relate to the player's intention. ${ }^{6}$ This is not mere interface activity. If there are many buttons and knobs for the player to twiddle, but all this twiddling has little 
effect on the experience, there is no agency. Furthermore, the effect must relate to the player's intention. If, in manipulating the interface elements, the player does have an effect on the world, but they are not the effects that the player intended ... then there is no agency.

(Mateas \& Stern 2005, p. 21)

Three elements stand out from this definition of agency when applied to an art museum environment:

- intention; that is, the defining of goals, large or small

- action; that is, an active participation element, the 'doing' part

- outcome/effect; that is, a result in line with the goals originally set

It should be stressed that all elements are necessary to create agency.

As one can infer from this definition of agency, participatory practices don't necessarily create agency as this also depends on how successfully they use design, implement the project and on the way in which results/ outcomes are shared and made visible (or not). In order to trigger agency, rigorous design of participatory activity is essential. As noted by Simon (2010) and Mateas \& Stern (2005), the balance between constraints (material and formal) is essential for the player/participant to experience agency. However, it is not the case that participatory practices should be offered by the institution or the artist without any rules or framing. A game without rules is not fun to play. Instead, the design should ensure a balance between constraints and respect for the participant's agency (that is, their intention, action and output).

\section{Agencies in the art museum}

Art museums, along with many other museums, can therefore be perceived as sites where various agencies clash, especially if we think of the museum not as a whole entity but as a panel of individual agencies (that of the people working in the museum). Hein posits that the museum is an "ethically freighted entity" that "exists over and above the individual people who work there or are in charge", further arguing that it "must be understood that such identities interlace insofar as the museum's decisions and agency take the form of human beings thinking, deciding, and acting in concert" (Hein 2011, p. 215). Similarly, Gilbert argues that museums tend to absorb individual agencies and render them invisible (Gilbert 2016). This composite agency of the museum creates a tense field of practice, and as Lagerkvist posits, "diversity in itself makes controversy unavoidable” (Lagerkvist 2006, p. 54).

But which agencies are in conflict in an art museum? There is first the perceived agency of the overall institution (expressed in its board nomination, its regulations, its budget allocation or its mission statement, for 
example). Then there are the agencies of various departments (conservation, curatorial, education, marketing etc.). The various individuals in each department also have a certain amount of agency at stake. Then, following in Latour's and Larson's footsteps, there is the agency of the objects exhibited (Latour 1993; Larson 2009). Such objects have a "multivocal quality" (Larson 2009, pp. 243-244). Not to be forgotten, the agency of the exhibition space allows or promotes certain practices within the institution. ${ }^{7}$ The agency of the external stakeholders should also not be underestimated in a public institutional context: artists, politicians, funders etc., all have agency that impacts on the museum. Finally, there is the public agency, on which this chapter seeks to focus its attention.

\section{Agency, knowledge production and learning in the art museum}

As the role of the museum evolved, matters of emancipation and inclusivity came to the fore (Sandell 2003; Jung 2010; Sitzia 2017). It is within that framework that public agency came under scrutiny. Public agency is closely linked to issues of knowledge production and conceptions of learning. Indeed, if we consider public agency as a process (intention followed by action leading to an outcome), the outcome of this process is a form of knowledge production. The process itself, the ways in which this knowledge is produced, is a learning process. For public agency to take place there must be an intention, action and output. As mentioned, this output can be identified as various forms of knowledge production.

Knowledge has been usefully defined by Gottschalk as a cluster concept with seven characteristics. According to Gottschalk Mazouz, knowledge:

- has a practical aspect

- is person-bound or not (personalized or represented knowledge coexist and are dependent)

- has a normative structure

- is internally networked (linked to existing internal knowledge)

- is externally networked

- is dynamic

- has institutional contexts

(Gottschalk-Mazouz 2008)

This definition of knowledge shows how it has gradually expanded beyond factual, normative information and is supplemented by the development of diverse individual cognitive skills (such as analytical, critical, internal and external networking skills etc.), various individual emotional skills (such as empathy, expanded imagination, creativity etc.), a wide variety of individual psychomotor skills (such as how to look at a painting, move in a limited space, manipulate an artwork etc.) as well as 
a range of social skills (normative museum behaviour or communication skills, for example).

These processes of knowledge production are linked to the agency of the museum public. Indeed, while the knowledge produced has an institutional context, this knowledge impacts on and is impacted by the ability of the public to make independent critical decisions.

It is precisely in that process of knowledge production that learning in the art museum takes place. As noted above, knowledge production and therefore learning in the art museum goes well beyond cognitive engagement and information transfer, and extends into emotional, psychomotor and social learning and skills development (Sitzia 2018). As Illeris noted, there is not necessarily a disjunction between personal and social forms of learning in the museum (Illeris 2006, p. 23), and the agency of participants can be individual or collective. However, all these various learning relationships imply various levels of participation and also various levels of agency on the part of the public and the institution.

\section{Accepted modes of public agency in the art museum}

There are standard modes of accepted public agency in museums. As Hill noted, traditionally, public agency in museums is limited to specific areas such as volunteering, donating or visiting (Hill 2011, p. 220). However, new modes of participation have encouraged a shift in accepted forms of public agency in the museum. Participatory practices can be seen as particularly tense areas in terms of agency negotiation because a certain amount of authority is given from the institution and its myriad individual agencies to the public. As Cornwall stressed, "participation as praxis is, after all, rarely a seamless process; rather, it constitutes a terrain of contestation, in which relations of power between different actors, each with their own 'projects', shape and reshape the boundaries of action" (Cornwall 2008, p. 276). I believe the use of agency as a measuring factor - and as a promotion of deeper participation (especially the link between outcome and intention) - can be beneficial as a framework to further think about participation in art museums.

\section{Defining participation through agency}

Participatory practices in art museums are complicated by issues of the autonomy of the artwork and the social engagement of the artist or the institution. This has led to a myriad of definitions and understandings of participation within the artistic field. In the art museum, the term 'participation' has come to cover a range of public, institutional and artistic practices ranging from attendance to contribution, collaboration, interpretation, co-creation of artworks or events and collection management activities. This disparity in the use of the term often leads to problems of 
communication and expectation within the art institutions themselves and between art museums and their funding bodies, the public and the artists involved. ${ }^{8}$

Researcher Anna Elffers and I therefore attempted to build a scale of participation specific to the art museum field (2016). We posited that participation in the art museum created a specific type of challenge because of the various fields involved: artists and artworks, curatorship, education and marketing. ${ }^{9}$ The choice of the scale format was linked to recurring issues of measurement of the impact of the arts and concerns from the field over token participation. Vestergaard Knudsen has traced the history of such participation ladders (2016, p. 194). By working in that tradition and building on Arnstein's model, we created a scale of the field's understanding of participation ranging from attendance to co-creation of artworks and events. The scale aimed to facilitate internal and external communication about what participation means, what are the goals of the institution as a whole and what are the intended outcomes (for the institution and the audience). At the bottom of our art museum participation scale, on the negative side, was attendance, followed by contribution, collaboration and interpretation/co-creation of meaning. At the very top of the scale, on the positive side, was co-creation of an artwork/event. The aim of this scale was to clarify various levels of participation and help institutions better understand that all participation is not equal.

However, a young researcher, Noguera Vich, questioned our scale, asking what it actually measured. ${ }^{10}$ I first tried to explain it through the distinction made by Kothari between presence, performance and power (Kothari 2001). But the core issue then became one of power, which didn't reflect the reality of the complexity of art museum participatory practices. A visitor attending the museum already holds some form of power by virtue of attending the museum. So while power is indeed essential in the participatory dynamics in museums, I felt this should not be the measuring unit of the scale because choosing to enter a museum is already justifying and supporting the existence of the institution, for example. ${ }^{11}$ As Cornwall pointed out, most of these ladders have been created with a good/bad implication and a "focus on the intentionality, and associated approach, of those who initiate participation" (2008, p. 270), when what we were originally trying to represent was what happened on the side of the participant (rather than the institution). In the meantime, the scale itself needed to be updated to encompass new types of participatory practices emerging in the field that relate to governance aspects of institutions, such as participatory collection management, which I added at the very top of the scale.

This shift in practice led me to ask whether the participation had more to do with the audience's sense of agency. Is agency the measure of all things participatory? Indeed, if one considers the definition of agency as intention, action and output/effect, it aligns with thinking on participatory 


\section{Emilie Sitzia}

practices and emancipation of the public (Rancière 1991; Jung 2010; ten Thije 2018). But it is also quite clear that in the context of agency, the ladder format oversimplifies the situation. This format doesn't reflect the variety of practices that reside under the same "label"; for example, cocreation can mean a myriad of things depending on the museum, the national and even regional environment or the design. Furthermore, as Cornwall notes, "being involved in a process is not equivalent to having a voice" $(2008$, p. 278). Therefore, it is important to clarify what kind of agency is being promoted by the institutions in various types of participatory practices, what kind of knowledge is being created for whom and what kind of learning framework underpins those practices that already assume and encourage a certain agency dynamic.

\section{Public agency, knowledge creation and learning in the art museum}

In order to answer these questions, this chapter focuses on three key types of participatory practices: meaning making, co-creation of artworks or events and collection management activities. I outline below what should happen in theory. Further field research is needed to confirm this theoretical model. These three types of participatory practices have been chosen as they are often perceived as particularly productive in terms of public agency and are common practices in art museums. They represent a range of engagement with the public and a variety of ideological choices in the art museum environment. However, such practices are not unambiguous. Each meaning-making, co-creation and collection management activity will be very different depending on the museum, the various contexts and the participants themselves. I aim here to look at the underlying structures and agency dynamic implied in such models. As Kirchberg points out, museum visits are a combination of "determining structures and individual determination" (Kirchberg 2007, p. 118). The determining structures for participatory practices are their knowledge creation processes and underpinning learning theories and values.

\section{Meaning making}

As a form of participation, meaning making is debated: just how participatory is it? Indeed, attending an art exhibition and interpreting works seem to be a rather minimal and superficial form of participation. However, Falk and Dierking argue convincingly for meaning making as an important participatory activity (2000). Similarly, Hill argues that interpretation is a form of "performance of identity" (Hill 2011, p. 221), and Csikszentmihalyi sees it as a core activity to trigger creativity (1996). Such participatory activities can take the form of label-writing exercises 
and interactive guided tours but also simply "response" exercises such as post-it walls or social media reactions to the works.

If we consider the form public agency takes in the meaning-making process, intention from the public is present. It is a very individual form of intention that is linked to a visitor's wish to attend an exhibition, to encounter the artworks and to spend time pondering those artworks, as well as to the visitor's ability to network existing knowledge. Therefore, the audience's intention is definitely present in meaning-making activities. Action, the second requirement for agency, is present, but it is an abstract, intellectual and cognitive form of action. By recognizing specific patterns and by developing internal and external networks, the audience member is actively shaping and interacting with the artwork. Cognitive and emotional learning take place and as such the outcome/effect is limited to knowledge construction in the learners themselves and is therefore not necessarily visible and shared unless the design of the activity actively plans for it.

In terms of the learning model, we can say here that this type of participation matches Rancière's model of the ignorant schoolmaster (Rancière 1991). The role of the "ignorant museum" is then to choose objects "chose commune" - and promote engagement with those objects from the audience (Sitzia 2017). The learning is focussed on the individual and assumes an equality of intelligence. Jung argued that such a model could reduce elitism in the institution (2010) as it would not only take the object seriously but also the meaning ascribed by the audience onto this object (Sitzia 2017).

In terms of knowledge production, the public is the main beneficiary of the knowledge created. The institution is only a beneficiary of this type of participation if it sets up a way to collect the results of this meaningmaking process and then uses them in its cataloguing or mediation programme or to inform further acquisition, for example. Artists rarely have access to the results of this meaning-making process and therefore would not be considered beneficiaries in this type of participatory model. ${ }^{12}$

Meaning making, in terms of public agency creation and knowledge production, is then a productive form of participatory practice. The learning model underpinning such participatory activities (while debated as a form of participatory practice) implies a relatively balanced relationship of power and active public agency.

\section{Co-creation}

Co-creation is often seen in the art world and in policy development as an ideal form of participation. Such participation can take the form of the co-creation of an event, exhibition or an artwork and typically involves the bodies, minds or experience of the participants. In reality, such projects are, and often need to be, relatively controlled. Being 


\section{Emilie Sitzia}

invited to engage in these types of participatory practices doesn't necessarily create agency. There is a difference between giving people choice within a limited environment and giving them agency. Of course, the participants will have decided to "play", so there is an intention, but it is very limited (mostly the intention to participate). This is especially true if the institution/artist didn't reveal its broader objectives. The intention of the institution/artist is not necessarily divulged when engaging an audience in a co-creation process: this further reduces the actual agency of the participants. Because public intention is not necessarily as free and individual in this form of participation and because of its more collective and negotiated nature within an existing frame, it shapes the kind of agency (if any agency at all) given to the participant. For example, being a participant in a participatory artwork and being given a card to read out loud limits (if not erases) the agency of the participants.

In such practices, action on the part of the audience can be abstract (such as coming up with a consultation process tool) but can also be very concrete (such as building an artwork or organizing an event). Learning in that context is more complex and layered. Cognitive and psychomotor learning can happen depending on the project, while emotional learning and social learning are almost always present in such contexts. The outcome/effect is also more collective and is commonly perceived as simultaneously identity building and community building.

In terms of learning theory, experiential learning and social learning are more relevant. Experiential learning asks for a range of modes of engagement and a reflection on the process. As explained by Dewey:

To "learn from experience" is to make a backward and forward connection between what we do to things and what we enjoy or suffer from things in consequence.

It is therefore important that for such projects to be learning experiences, they must have built into their design a reflective moment for both the institution and the participants.

As for social learning, Wenger outlines that in order to enter a community of practice one needs three basic modes of identification: engagement (with concrete participatory practices), alignment (positioning oneself in a community and its framework) and imagination (Wenger 1998, p. 189). These three processes often happen in the context of cocreation. Furthermore, for Wenger, learning is at the centre of the basic components of communities of practice. Learning is then linked to practice (learning as doing), to community (learning as belonging), to identity (learning as becoming) and to meaning (learning as experience). They are all key elements in the learning process and in co-creative participatory practices (Wenger 2009, p. 211). 
In the case of co-creation, the agency created is limited and the boundaries and control of the institution, even when following best practices, remain quite high. The knowledge production benefits the participating public (if a reflective moment is integrated in the design of the co-creation project, which is not always the case), the institution (as it centralizes and displays the common knowledge created by the project) and the artist (as a member of the community of practice within the co-creation process). Therefore, co-creation, which is often perceived as a very "participatory" practice, in effect creates a rather limited public agency.

\section{Governance: Collection management}

Participatory collection management is one of the most debated forms of participatory practice in the museum. It is often seen as threatening the expertise of museum staff and is even perceived by some as a form of populism. But there are true democratic forms of participatory practices involving the public in the purchasing, collecting, conserving and exhibiting of collections. Such activities can take many forms, from citizen science and collection tagging, to crowdsourcing artistic commissions.

However, as Lagerkvist highlights in his study of the Museum of World Culture, there are limitations to such practices. Even when the participants worked on the project for over a year, "The Museum's limits for inclusion in professional areas were actually quite tight. Including nonspecialists in an intense specialist process of a major exhibition seemed both difficult and hazardous considering the time pressure we were working under" (Lagerkvist 2006, p. 59). Indeed, it is in these environments that the audience's agency clashes in the most visible way with issues related to matters of museum staff expertise. Museum conservators, curators and managers have often studied and researched their area of expertise extensively and often have difficulty seeing the institutional benefits of such participatory practices.

If we look at the forms of agency delivered by this model, intention is again limited and negotiated within existing frameworks. The public is rarely given "carte blanche" and must instead function within very strict boundaries. Action on the part of the audience is important but is also heavily negotiated. The action in this context can be abstract (developing an exhibition concept, for example) but can also be practical (management, selection and installation of artworks). The outcome is again more collective: building identity and community is also at the core of this practice. Learning is at its richest: a combination of cognitive, emotional, psychomotor and social learning.

In terms of learning theories, Jarvis's model of learning from primary experience is suitable to describe the process. For Jarvis, "all human learning begins with disjuncture - with either an overt question or with a sense of unknowing" (Jarvis 2009, p. 22). In this context, the social aspect and 


\section{Emilie Sitzia}

the interaction between specialists and audience are key to learning, as learning is both existential and experiential. In his learning model, sensation or disjunction initiate and enable learning. However, to Jarvis, visitors cannot make meaning alone; they need a social interaction to be enabled as a learner. Therefore, the participatory practice must provide for a social context that encourages interaction between expert and participants.

In terms of knowledge production, while the public certainly acquires knowledge, the institution is the biggest beneficiary of such forms of participatory practices. The public learns about the institutions' rules and limitations and a little about the expertise of the staff. The museum experts, on the other hand, gain a great insight into their audiences' set of values and behaviours. The artists, if involved at all, benefit the least from such practices.

Therefore governance, which is perceived as the ultimate form of participatory practice in terms of audience involvement in the institution, also doesn't necessarily create public agency.

\section{Conclusion: A call for a diversity of participatory practices and going beyond the ladder model}

This theoretical exploration of various forms of participation and of public agency within these practices shows that there is enormous value in diversity of participatory practices. While some forms of participatory practices will lead to a specific form of public agency that will itself allow for the development of a specific type of knowledge, others will benefit the institutions or society more broadly while limiting the agency of the public.

From this analysis it becomes clear that researchers and institutions should abandon scales as a way to model participatory practices. The scale format implies a hierarchy from full to empty participation when this chapter has shown that various types of agency are desirable and that some practices that are at the very bottom of such scales (such as meaning making) can actually translate into very high public agency. Therefore, institutions and researchers should look not for hierarchy but into the benefits of various formats and move towards a different form of modelling. This could take diverse forms. For example, Farrington and Bebbington (1993) proposed a model with two axes to assess participation according to depth (which would correspond to individual agency) and breadth (which could be understood as more general social impact). This could be adapted to art museum participation. Another potential matrix could be based on Rolan's records continuum model of archival practices (2017). This model is more process- than outcome-focussed. It would need adaptation as it is concerned with archival practices, but these are close enough to museum practices to be of use. One could also 
imagine a simpler mobile scale that would shift depending on the goals/ desired outcome (increased agency, building of community etc.) and the point of view adopted (institution, artist or visitor).

It is also important for institutions and policy makers to acknowledge that some forms of participation reinforce exclusion by diminishing an individual's agency. As Cornwall rightly noted, "although the term itself evokes a warm ring of inclusion, 'participatory' processes can serve to deepen the exclusion of particular groups unless explicit efforts are made to include them" (Cornwall 2008, p. 277). As such, a specific effort should be made to respect agency, especially when working with vulnerable groups. All researchers agree that respecting agency (that is, the intention, action and outcome continuum of the visitor) is essential in inclusion/exclusion mechanisms, strengthening self-worth and nurturing the voices of audiences (Newman \& McLean 2004; Lagerkvist 2006; Cornwall 2008; Lynch 2011, 2017).

\section{Notes}

1 But there is a lack of in-depth reflection on the fact that social inclusion does not necessarily lead to audience empowerment (Lynch 2017; Coffee 2008).

2 Learning is nowadays considered a key role of art museums (Hooper-Green hill 1999).

3 The various types of learning in museums is important to my argument about agency and will be detailed further on in the chapter. Indeed the various learning frameworks adopted by museums when designing participatory practices impact on agency dynamics.

4 On the definition of participatory practices in the artworld, see Elffers and Sitzia (2016). For the purpose of this chapter the definition of participation will be re-developed in the section "Defining participation through agency".

5 These three practices have been chosen as they represent a range of engagement with the public, allow for a variety of ideological choices and are the most commonly used participatory techniques in the art museum environment.

6 I obviously disagree here with the conflation of agency and the feeling of empowerment (see earlier paragraph), but the rest of the definition seems very helpful.

7 The agency of artistic objects and museum spaces can arguably be seen as an extension of the agency(ies) of artists or the institution. But I will not debate these positions in this chapter.

8 Many examples of such misunderstandings are present in the rich volume of case studies put together by McSweeney and Kavanagh (2016).

9 It is possible that the same variations are found in other types of museums, but further research is necessary to back up such a claim.

10 He went on to write a very interesting master's thesis, Museum participation or empty rituals?, at Maastricht University in 2017.

11 I then tried to align it with White's work by attempting to apply nominal, instrumental, representative and transformative participation to our existing scale (White 1996). But this attempt didn't help clarify the nature of what is being measured.

12 This, of course, only applies to contemporary art museums or galleries. 


\section{Emilie Sitzia}

\section{References}

Bal, M 1996, Double exposures: The subject of cultural analysis, Routledge, New York.

Borg, C \& Mayo, P 2010, 'Museums: Adult education as cultural politics', New Directions for Adult and Continuing Education, Fall, pp. 35-44.

Cameron, F 2015, 'The liquid museum: new institutional ontologies for a complex, uncertain world', in Witcomb, A \& Message, K (eds), The International Handbooks of Museum Studies, Volume 1: Museum Theory, Wiley-Blackwell, Oxford, pp. 345-361.

Clifford, J 1999, 'Museums as contact zones', in D Boswell \& J Evans (eds.), Representing the nation: A reader: Histories, heritage, and museums, Routledge, London, pp. 435-457.

Clover, DE 2015, 'Adult education for social and environmental change in contemporary public art galleries and museums in Canada, Scotland and England', International Journal of Lifelong Education, vol. 34, pp. 300-315.

Coffee, K 2008, 'Cultural inclusion, exclusion and the formative role of museums', Museum Management and Curatorship, vol. 23, no. 3, pp. 261-279.

Cornwall, A 2008, 'Unpacking “participation”: Models, meanings and practices', Community Development Journal, vol. 43, no. 3, pp. 269-283.

Csikszentmihalyi, M 1996, Creativity: Flow and the psychology of discovery and invention, Harper Collins, New York.

Dewey, J [1916] 2008, Democracy and education, Project Gutenberg, Champaign, IL, viewed 18 January 2019, www.gutenberg.org/les/852/852-h/852-h. htm\#link2HCH0008.

Elffers, A \& Sitzia, E 2016 'Defining participation: Practices in the Dutch artworld', in K McSweeney \& J Kavanagh (eds.), Museum participation: New directions for audience participation, MuseumsEtc, Edinburgh, pp. 39-67.

Falk, J \& Dierking, L 2000, Learning from museums: Visitor experiences and the making of meaning, AltaMira Press, Walnut Creek, CA.

Farrington, J \& Bebbington, A 1993, Reluctant partners: Non-governmental organisations, the state and sustainable agricultural development, Psychology Press, Routledge, London.

Ferguson, B, Greenberg, R \& Nairne, S 1996, Thinking about exhibitions, Routledge, London.

Fyfe, G 1995, 'A Trojan horse at the Tate: Theorizing the museum as agency and structure', Sociological Review, vol. 43, no. 1, pp. 203-228.

Gilbert, L 2016, “Loving, knowing ignorance”: A problem for the educational mission of museums', Curator The Museum Journal, vol. 59, no. 2, pp. 125-140.

Golding, V 2009, Learning at the museum frontiers: Race, identity and power, Routledge, London.

Gottschalk-Mazouz, N 2008, 'Internet and the flow of knowledge: Which ethical and political challenges will we face?', in Wittgenstein and the philosophy of information, Ontos Verlag, Frankfurt, pp. 218-222.

Hein, G 1999, 'The constructivist museum', in E Hooper-Greenhill (ed.), The educational role of the museum, Routledge, London, pp. 73-79.

Hein, H 2011, 'The responsibility of representation: A feminist perspective', in J Marstine (ed.), The Routledge companion to museum ethics: Redefining ethics for the twenty-first-century museum, Routledge, London, pp. 112-126. 
Hill, K 2011, 'Thinking about audience and agency in the museum: Models from historical research', paper from the conference "Current issues in European cultural studies", organised by the Advanced Cultural Studies Institute of Sweden (ACSIS), Norrköping, 15-17 June, conference proceedings published by Linköping University Electronic Press, viewed 25 January 2019, www.ep.liu. se/ecp_home/index.en.aspx? issue $=062$.

Hooper-Greenhill, E 1992, Museums and the shaping of knowledge, Routledge, New York.

Hooper-Greenhill, E 1999, The educational role of the museum, Routledge, London. Illeris, H 2006, 'Museums and galleries as performative sites for lifelong learning: Constructions, deconstructions and reconstructions of audience positions in museum and gallery education', Museum and Society, vol. 4, viewed 15 December 2018, https://journals.le.ac.ukjojs1/index.php/mas/articleiview_j75.

Jarvis, P 2009, 'Learning to be a person in society', in K Illeris (ed.), Contemporary theories of learning, Routledge, New York.

Jordan, G, \& Weedon, C 1995, Cultural politics. Class; gender, race and the postmodern world, Blackwell, Oxford.

Jung, Y 2010, 'The ignorant museum: Transforming the elitist museum into an inclusive learning place', in N Abery (ed.), The new museum community: Audiences, challenges, benefits, MuseumsEtc, Edinburgh, pp. 272-291.

Kirchberg, V 2007, 'Cultural consumption analysis: Beyond structure and agency', Cultural Sociology, vol. 1, no. 1, pp. 115-135.

Kothari, U 2001, 'Power, knowledge and social control in participatory development', in B Cooke \& U Kothari (eds.), Participation: The new tyranny?, Zed Books, London.

Lagerkvist, C 2006, 'Empowerment and anger: Learning how to share ownership of the museum', Museum and Society, vol. 4, no. 2, pp. 52-68.

Larson, F 2009, An infinity of things: How Sir Henry Wellcome collected the world, Oxford University Press, Oxford.

Latour, B 1993, We have never been modern, Harvester Wheatsheaf, New York.

Lynch, B 2011, Whose cake is it anyway? A collaborative investigation into engagement and participation in twelve museums and galleries in the UK, Paul Hamlyn Foundation, London.

Lynch, B 2017, 'Migrants, museums, and tackling the legacies of prejudice', in C Bevelander \& P Johansson (eds.), Museums in a time of migration: Rethinking museums' representations, collections, and collaborations, Nordic Academic Press, Lund.

Mairesse, F \& Desvallées, A 2007, Vers une redéfinition du musée, L'Harmattan, Paris.

Mateas, M \& Stern, A 2005, 'Interaction and narrative', in K Salen \& E Zimmerman (eds.), Game design reader: A rules of play anthology, MIT Press, Cambridge, MA, pp. 642-669.

McCall, V \& Gray, C 2014, 'Museums and the "new museology": Theory, practice and organisational change', Museum Management and Curatorship, vol. 29, no. 1, pp. 19-35.

McSweeney, K \& Kavanagh, J (eds.) 2016, Museum participation: New directions for audience participation, MuseumsEtc, Edinburgh.

Newman, A \& McLean, F 2004, 'Presumption, policy and practice', International Journal of Cultural Policy, vol. 10, no. 2, pp.167-181. 


\section{Emilie Sitzia}

Nochlin, L 1972, 'Museums and radicals: A history of emergencies', in B O’Doherty (ed.), Museums in crisis, G. Braziller, New York, pp. 7-41.

Philip, MN 1992, Frontiers: Essays and writings on racism and culture, The Mercury Press, Ontario.

Rancière, J 1991, The ignorant schoolmaster: Five lessons in intellectual emancipation, trans. K Ross, Stanford University Press, Stanford, CA.

Rolan, G 2017, 'Agency in the archive: A model for participatory recordkeeping', Archival Science, vol. 17, pp. 195-225.

Sandell, R 1998, 'Museums as agents of social inclusion', Museum Management and Curatorship, vol. 17, pp. 401-418.

Sandell, R 2002, 'Museums and the combating of social inequality: Roles, responsibilities, resistance', in R Sandell (ed.), Museums, society, inequality, Routledge, London, pp. 3-23.

Sandell, R 2003, 'Social inclusion, the museum and the dynamics of sectoral change', Museum and Society, vol. 1, pp. 45-62.

Simon, N 2010, The participatory museum, Museum 2.0, Santa Cruz, CA.

Sitzia, E 2017, 'The ignorant art museum: Beyond meaning-making', International Journal of Lifelong Education, vol. 37, no. 1, pp. 73-87.

Sitzia, E 2018, 'The many faces of knowledge production in art museums', Muséologies. Les cahiers d'études supérieures, vol. 8, no. 2, pp. 141-157.

ten Thije, S 2018, The emancipated museum, Jap Sam Books, Amsterdam.

Vergo, P 1989, The new museology, Reaktion Books, London.

Vestergaard Knudsen, L 2016, 'Participation at work in the museum', Museum Management and Curatorship, vol. 31, no. 2, pp. 193-211.

Wenger, E 1998, Communities of practice: Learning, meaning and identity, Cambridge University Press, New York.

Wenger, E 2009, 'A social theory of learning', in K. Illeris (ed.), Contemporary theories of learning, Routledge, New York, pp. 209-218.

White, S 1996, 'Depoliticising development: The uses and abuses of participation', Development Practice, vol. 6, no. 1, pp. 6-15. 